\title{
PERAN PENDIDIK DALAM MENGHADAPI KERAGAMAN GAYA BELAJAR MURID
}

\author{
Hendrick Sine \\ Eagle Ministry \\ Jl. Nyengseret Gg. 1 No. 11, Bandung, Jawa Barat \\ hendrik.sine@gmail.com
}

\begin{abstract}
Abstrak: Pemahaman tentang gaya belajar murid sangatlah penting bagi guru, pendidik atau dosen. Hal ini bertujuan membangun pembelajaran yang efektif dan kreatif dalam meresponi keunikan gaya belajar peserta didik. Selain itu, disain bahan ajar dan pemakaian metode mengajar haruslah relevan dengan kebutuhan peserta didik. Namun realitanya pemahaman tersebut masih belum maksimal. Oleh karena itu diperlukan kompetensi pendidik dalam menyiapkan hal tersebut sehingga proses pembelajaran di kelas menjadi bermakna, menginspirasi, mencerahkan, kreatif, transformatif dan produktif. Metode penelitian yang digunakan dalam tulisan ini adalah metode kualitatif. Hasil penelitian ini menyimpulkan bahwa bila pendidik kurang pemahaman tentang gaya belajar anak dan gaya belajar dirinya dapat mengakibatkan pembelajaran tidak efektif dan kreatif. Sedangkan pendidik yang memahami gaya belajar yang berbeda dapat menciptakan proses pembelajaran yang efektif, kreatif dan produktif.
\end{abstract}

Kata Kunci: peran pendidik, keragaman gaya belajar, pembelajaran yang bermakna, kreatif dan efektif.

\section{THE ROLE OF EDUCATOR IN DEALING WITH THE DIVERSITY OF STUDENT LEARNING STYLES}

\begin{abstract}
An understanding on student learning style is very important for educators. It aims to build an effective and creative learning in responding students' unique styles of learning. In addition, the design of teaching materials and utilization of methods should be relevant to the needs of learners. However, the reality is that the understanding is still not maximal. Therefore, competence and role of educator is required in preparing it, so that the process of learning in class becoming meaningful, inspiring, enlightening, creative, transformative and productive. The research method used in this writing is qualitative method. The results of this study conclude that if the educator is lack of understanding about children's learning styles and their own learning styles, can cause learning process that is not effective and creative. Whereas the educators who understand the differences in learning styles will be able to create an effective, creative and productive learning process.
\end{abstract}

Keywords: role of educator, the diversity of learning styles, meaningful learning, creative and effective. 


\section{PENDAHULUAN}

Dunia pendidikan di tanah air perlu menata diri, dalam hal ini adalah sekolah dan perguruan tinggi teologi dalam menghadapi keragaman gaya belajar murid. Mengapa? Sebab peserta didik memiliki keragaman gaya belajar. Perbedaan gaya belajar murid acap kali membuat para pendidik kesulitan dalam menghadapi mereka. Tentu hal ini menjadi persoalan yang harus dikaji dan dijawab.

Itu sebabnya para pendidik harus terus berupaya mengasah diri, meningkatkan kemajuan diri agar menjadi lebih profesional dalam mendidik dan melakukan transmisi pengetahuan kepada nara didik yang beragam. Selain itu, pengembangan metode belajar juga perlu beragam sesuai dengan tujuan belajar. Demikian juga guru atau dosen harus merancang bahan ajar yang efektif dan kreatif sehingga menghasilkan proses pembelajaran yang bermutu.

Apa yang menjadi tujuan dalam penelitian ini? Tujuan penelitian ini adalah mengemukakan apa yang sepatutnya, diusulkan untuk memperlengkapi guru dan dosen supaya dapat mengelola pembelajaran efektif dan kreatif menghadapi keragaman gaya belajar peserta didik.

Apa manfaat penelitian ini? Secara teoritis studi ini bermanfaat bagi pembinaan warga jemaat Sekolah Minggu, bermanfaat juga dalam konteks pendidikan Kristen di sekolah dan perguruan tinggi Kristen. Kualitas pendidik penentu mutu pendidikan atau pembinaan, karenanya pendidikan terhadap peserta didik merupakan tanggung jawab para pendidik. Apalagi pendidikan terhadap murid merupakan kehendak dan perintah-Nya.

Secara praktis hasil penelitian ini diharapkan bisa berguna menjadi masukan bagi para guru dan dosen dalam rangka peningkatan mutu pengajaran terhadap peserta didik.

\section{METODE PENELITIAN}

Studi ini menggunakan penelitian kualitatif. Menurut Moleong, metode kualitatif artinya peneliti melakukan pengamatan, analisis terhadap data atau dokumen dan melakukan wawancara. Metode ini dipakai karena menyesuaikan metode kualitatif lebih mudah daripada berhadapan dengan kenyataan jamak, metode ini dapat menghubungkan antara peneliti dan responden, metode ini lebih dapat menyesuaikan diri dengan banyak penajaman pengaruh bersama terhadap pola-pola nilai yang dihadapi (Moleong, 2013, p. 9-10). Penelitian kualitatif adalah suatu pendekatan penelitian yang mengungkap situasi sosial tertentu dengan mendeskripsikan kenyataan secara benar, dibentuk oleh kata-kata berdasarkan teknik pengumpulan dan analisis data yang relevan yang diperoleh dari situasi yang alamiah (Satori \& Komariah, 2011, p. 25). Dapat dikatakan bahwa pendekatan penelitian kualitatif adalah peneliti melakukan kajian dan observasi terhadap data, dan wawancara kepada responden atau mengungkap kondisi sosial tertentu berdasarkan realitas yang sesungguhnya dengan penjelasan atau narasi yang didapatkan secara alamiah di lapangan.

Teknik pengumpulan data di lapangan melalui observasi, wawancara dan dokumen. Penelitian kualitatif secara umum sering disebut pendekatan kualitatif deskriptif. Peneliti berusaha menganalisis data dengan semua kekayaan wataknya yang penuh nuansa, sedekat mungkin dengan bentuk aslinya seperti waktu dicatat. Itu sebabnya kedekatan hubungan transaksi antara peneliti dengan yang diteliti penting (Sutopo, 2006 , p. 40). Metode kualitatif ini digunakan untuk memperoleh data dari sumber primer di lapangan. Studi lapangan untuk mengetahui pemahaman dan upaya guru-guru atau dosen mengahadapi keragaman gaya belajar murid.

Pada studi kepustakaan langkah kerjanya penulis akan melakukan studi 
literatur dengan menggunakan data primer (misalnya karya DePorter \& Hernacki yang berjudul Quantum Learning, dan karya Tobbias yang berjudul Cara Mereka Belajar) dan sekunder. Sumber informasi diperoleh dari buku-buku dan jurnal terkait dengan topik penelitian, pemikiran para tokoh pendidikan Kristen tentang keragaman gaya belajar serta karakteristik peserta didik yang khas. Informasi dari literatur itu dihimpun serta dinalisis, dan dibandingkan lalu diberi tanggapan. Penulis melakukan studi ini guna memperoleh data untuk membangun teori.

Selanjutnya mengemukakan saransaran konstruktif guna peningkatan mutu pengajaran guru dan dosen. Saran-saran tersebut berdasarkan data atau informasi yang dihimpun, bertitik tolak dari hasil kajian studi literatur, pemikiran para tokoh pendidik Kristen, juga dengan mempertimbangkan data dari penelitian lapangan. Sesudah itu, penulis akan menyimpulkan hasil dari penelitian.

\section{HASIL DAN PEMBAHASAN}

\section{Gaya Belajar Murid dan Keragamannya}

Uraian berikut ini membahas apa itu gaya belajar, ragam gaya belajar murid, serta faktor-faktor yang membentuk gaya belajar. Hal-hal ini penting karena memang guru perlu untuk mengenal cara atau gaya belajar nara didik dengan baik sehingga mampu membimbing mereka dengan efektif dan efisien.

\section{Pengertian Gaya Belajar}

Menurut Tobias, "masing-masing anak melihat sesuatu dengan cara yang berbeda. Setiap anak adalah individu yang unik, yang mempunyai kelebihan dan kesukaan sendirisendiri. Karunia atau bakat pribadi yang disebut gaya belajar" (Tobias, 2000, p. 5).

Pandangan lain tentang hal itu juga dikemukakan oleh Suyadi, gaya belajar adalah "seni" berpikir melalui kecenderungan masing-masing anak (Suyadi, 2014, p. 154; bdk. Suyono \& Hariyanto, 2012, p. 147).
Nasution mendefinisikan gaya belajar adalah cara yang konsisten yang dilakukan oleh seseorang murid dalam menangkap stimulus dan informasi, cara mengingat, berpikir, dan memecahkan soal. Tidak semua orang mengikuti cara yang sama, karena setiap orang berbeda-beda dalam belajar (Nasution, 2011, p. 94). Bagi Dryden and Vos, arti gaya belajar adalah suatu kekuatan yang khas dalam diri manusia. Gaya tersebut khas sebagaimana tanda tangan. Tidak ada satu gaya belajar yang lebih baik atau lebih buruk daripada gaya belajar yang lain. Semua kelompok secara budaya, akademis, laki-laki dan perempuan memiliki gaya belajar (Dryden \& Vos, 2001, p. 340; bdk. DePorter \& Hernacki, 2013).

Berdasarkan pandangan-pandangan tersebut, dapat disimpulkan bahwa gaya belajar adalah suatu kemampuan, potensi yang khas dalam diri setiap orang. Potensi ini dapat dieksplorasi melalui cara berpikir, menyerap informasi, mengelola informasi yang diterima, kemudian mengungkapkan suatu perbuatan belajar serta mengemukakan solusi terhadap suatu persoalan. Potensi ini berbeda-beda dalam diri manusia. Dan hal ini merupakan anugerah Tuhan bagi setiap manusia.

\section{Jenis-jenis Gaya Belajar}

Dilihat dari jenisnya, terdapat kemajemukan gaya belajar para peserta didik. Menurut tokoh-tokoh pendidikan dapat dilihat sebagai berikut:

\section{Antony F. Gregorc}

Menurut teori Gregorc (Mind Style, n.d.), tidak ada dua orang yang sama dalam cara berpikirnya. Setiap individu cenderung memandang dunia berdasarkan cara pemahamannya masing-masing. Cara setiap orang memandang sesuatu, disebut persepsi. Persepsi mempengaruhi apa yang orang pikirkan. Bagaimana orang membuat keputusan dan bagaimana kita menetapkan apa yang penting menurut kita. Persepsi juga 
menentukan kemampuan belajar atau gaya belajar setiap orang.

Selanjutnya, Gregorc menjelaskan dua kualitas persepsi yang dimiliki setiap individu yang berpikir, yakni persepsi konkret dan abstrak. Konkret, kualitas ini memungkinkan kita langsung menyerap informasi melalui panca indera: penglihatan, perasa, peraba, penciuman, dan pendengaran. Ketika kita menggunakan kemampuan konkret, kita hanya berurusan dengan apa yang ada di depan mata pada saat itu juga, nyata dan jelas terlihat. Kita tidak mencari arti yang tersembunyi. Tidak mengaitkan antara ide dan konsep. Sedangkan abstrak, kualitas ini memungkinkan kita untuk memvisualisasikan, melahirkan ide, memahami atau mempercayai apa yang sebetulnya tidak dapat dilihat. Ketika memakai kualitas abstrak, kita mengikuti bisikan hati, akal budi, atau membayangkan sesuatu. Kita ingin tahu apa yang tersembunyi di balik yang terlihat. Sesudah itu, berdasarkan teori Gregorc dikemukakan bahwa meskipun setiap orang menggunakan persepsi itu, baik konkret maupun abstrak, masing-masing cenderung merasa lebik enak ketika menggunakan salah satu di antara keduanya. Hal ini kemudian menjadi kemampuan dominan orang. Misalnya orang yang kualitas konkretnya lebih kuat biasanya lebih suka mendengarkan sesuatu yang langsung, harafiah, dan logis. Sebaliknya mereka yang abstrak lebih sering menemukan sesuatu dari pihak lain dibalik apa yang diucapkan lawan bicara.

Kemudian berdasarkan teori yang sama dijelaskan bahwa ada dua kemampuan untuk menyusun informasi yang didapat, yakni: sekuensial (teratur, menurut aturan bertahap) dan random (acak). Menurutnya, kemampuan sekuensial memungkinkan kita menyusun informasi secara teratur dan bertahap. Ketika menggunakan kemampuan sekuensial, kita mengikuti alur pikir yang logis, sebuah pendekatan yang umum dalam berurusan dengan informasi. Mereka yang kemampuan sekuensialnya kuat lebih suka melakukan sesuatu berdasarkan perencanaan, bukan mengandalkan dorongan hati. Kemampuan random memungkinkan pikiran kita menyusun informasi secara serabutan atau tidak teratur. Sewaktu kemampuan ini digunakan, ada kemungkinan beberapa tahapan terlewati. Tetapi tujuan akhir tetap tercapai. Bahkan kita bisa memulainya dari tengah, dari belakang, atau bahkan melangkah mundur. Mereka yang memiliki cara menyusun randomnya kuat, biasanya tidak berpikir panjang; mereka lebih spontan. Kesannya mereka tidak mempunyai perencanaan (bdk. Tobias, 2000, p. 16-17)

Berdasarkan pandangan tersebut di atas, dapat diklasifikasi menjadi dua aspek gaya belajar:

1. Persepsi, terdiri dari konkret dan abstrak. Artinya kita merespons sesuatu dengan persepsi konkret dan perpsepsi abstrak.

2. Penyusunan, yang terdiri dari sekuensial dan random. Artinya kita menyusun informasi yang kita terima melalui kedua cara tersebut (sekuensial dan random).

Dengan demikian Gregorc (Mind Style, n.d.) mengemukakan empat jenis gaya belajar:

1. Sekuensial Konkret (SK). Ciri-cirinya: ulet, tradisional, sangat cermat, stabil, dapat diandalkan, konsisten, berpegang pada fakta, dan teratur.

2. Sekuensial Abstrak (SA). Ciri-cirinya: analitis, obyektif, berpengetahuan banyak, teliti, rapi, logis, tenang dan hati-hati, sistematis.

3. Random Abstrak (RA). Ciri-cirinya: peka, penuh belas kasih, cepat memahami, imajinatif, idealis, sentimentil, spontan, fleksibel.

4. Random Konkret (RK). Ciri-cirinya: cepat, berdasar kata hati, selalu ingin tahu, realistis, memiliki daya cipta, inovatif, naluriah, sangat berani.

Peran Pendidik Dalam Menghadapi Keragaman ... 
David Kolb

Menurut David Kolb, gaya belajar dilihat dari empat aspek (Kolb Learning Style, n.d.), yakni:

1. Pengalaman konkret. Artinya mereka mampu menerapkan pembelajaran dalam situasi nyata untuk memecahkan masalah yang dihadapi.

2. Berpikir secara konseptual abstrak. Artinya terampil dalam melaksanakan aplikasi praktis dari gagasannya dan menggunakan logika deduktif untuk memecahkan masalah.

3. Observasi atau pengamatan reflektif. Artinya merespon informasi yang diberikan dengan baik jika mereka diberikan waktu untuk berefleksi.

4. Pengalaman aktif. Artinya mampu menggunakan logika untuk memecahkan masalah.

Dari empat aspek dalam pengalaman belajar itu, David Kolb mengemukakan empat gaya belajar yang merupakan kombinasi dari dua aspek yang dikemukakan yaitu pengalaman konkret dan konseptualisasi abstrak. Empat gaya belajar itu antara lain:

1. Converger, disebut sebagai gaya belajar tipe1. Cirinya adalah berpikir secara konseptual abstrak dan pengamatan aktif. Misalnya, tipe ini suka menggunakan logika deduktif untuk memecahkan masalah. Juga anak didik yang bertipe ini terampil dalam melaksanakan aplikasi praktis dari gagasannya. Supaya tipe ini belajar lebih efektif, maka guru harus bertindak sebagai pendorong.

2. Diverger, disebut gaya belajar tipe 2 . Cirinya berpikir secara konseptual abstrak dan pengamatan reflektif. Tipe ini merespons informasi lebih cepat, bila diberi waktu untuk berefleksi. Tipe ini akan menjadi efektif jika guru berperan sebagai pakar.

3. Assimilator, disebut sebagai gaya belajar tipe 3. Cirinya berpikir secara konseptual dan pengamatan reflektif. Tipe ini cakap dalam membangun model teoritis dengan penalaran induktif. Guru harus bersikap sebagai pelatih dalam melatih anak didik sehingga menjadi lebih efektif.

4. Accommodator, disebut sebagai gaya belajar tipe 4. Cirinya adalah penggunaan pengalaman nyata dan eksperimentasi aktif. Tipe ini terampil dalam mengaitkan dunia nyata dengan pembelajarannya. Mereka tidak hanya membaca buku, namun aktif mempraktikan apa yang telah dipelajarinya. Oleh karena itu guru harus berperan sebagai fasilitator, dan memberi keluasan serta memaksimalkan kesempatan murid untuk menemukan sesuatu bagi dirinya sendiri sehingga efektif dalam pembelajaran (bdk. Suyono, 2012, p. 155-156).

\section{Faktor-faktor yang Membentuk Gaya Belajar Murid}

Suyadi mengutip pandangan Rita Dunn, mengemukakan bahwa banyak variabel yang mempengaruhi gaya belajar seseorang, antara lain: faktor-faktor fisik, emosional, sosiologis, dan lingkungan. Sebagai contohnya Suyadi membuat perbandingan: sebagian anak lebih senang bermain secara berkelompok daripada sendirian, sedangkan anak yang lain lebih suka bermain sendirian daripada berkelompok; seorang anak lebih senang bermain mobil-mobilan, sedangkan anak yang lain lebih menyukai boneka; seorang anak yang lain lebih senang bermain dengan iringan musik, sementara anak yang lain lebih senang bermain dengan sunyi senyap; anak tertentu senang bermain di kegelapan, sedangkan anak yang lain ada yang takut dengan suasana gelap. Hal ini disebut dengan gaya bermain atau gaya belajar (Suyadi, 2014, p. 155; bdk. DePorter \& Hernacki, 2012, p. 110). 
Dryden dan Vos, mengemukakan halhal yang membentuk gaya belajar anak adalah: lingkungan fisik seperti cahaya, suara, suhu, tempat duduk, dan sikap tubuh; kebutuhan emosional. Emosi sangat berperan penting dalam proses belajar. Emosi adalah kunci bagi sistem memori otak. Muatan emosi dari presentasi dapat berpengaruh besar dalam memudahkan anak didik untuk menyerap informasi dan ide; kebutuhan sosial. Tidak sedikit orang yang suka belajar sendiri, yang lain suka belajar berkelompok. Dan juga anak-anak menginginkan kehadiran orang dewasa atau bimbingannya dalam pembelajaran (Dryden \& Vos, 2001, p. 351).

Dengan demikian dapat disimpulkan bahwa hal-hal yang membentuk gaya belajar seseorang adalah: faktor intelegensia atau intelektual murid, faktor kemauan/hobi, bakat, motivasi, kebiasaan, emosi, faktor budaya, lingkungan keluarga dan lingkungan sosial.

\section{Pembelajaran Kreatif Meresponi Gaya Belajar Murid}

Uraian berikut ini menjelaskan tentang pengertian pembelajaran kreatif, metode pembelajaran, bagaimana guru atau dosen menghadapi gaya belajar murid. Kegunaan uraian ini adalah agar guru dan dosen dapat memahami dan meningkatkan kreatifitasnya dalam merancang bahan ajar dengan memakai metode belajar yang relevan dalam menghadapi keragaman gaya belajar nara didik.

\section{Pengertian Pembelajaran Kreatif}

Menurut Lawrence $O$. Richard, "Mengajar secara kreatif berarti dengan sengaja atau secara sadar dan secara efektif memusatkan perhatian pada aktivitasaktivitas belajar yang dapat meningkatkan tahap belajar peserta didik." (Richard, 2000, p. 98). Selanjutnya Richard menjelaskan bahwa kelemahan dari kebanyakan guruguru tidak mengerti tentang tahap belajar yang lebih tinggi. Dan kalau mereka belum menginsafi hal ini tentu mereka tidak dapat menolong peserta didik (Richard, 2000, p. 99). Sedangkan menurut Setiawani, "kegiatan belajar yang kreatif adalah kegiatan yang diberikan kepada anak didik sebagai respons setelah menerima pengajaran kebenaran Alkitab" (Setiawani, 2000, p. 112). Mengajar yang efektif hanya bisa dilakukan oleh orang yang berubah. Semakin guru berubah, semakin guru menjadi alat perubahan dalam hidup orang lain (Hendricks, 2009, p. 23; bdk. Zuck, 1972, p. 119). Berarti jika guru atau dosen ingin membawa transformasi kepada peserta didiknya, maka guru harus terlebih dahulu mengubah gaya hidupnya serta meningkatkan cara mengajar yang kreatif. Selanjutnya ia mengatakan: "pengajar yang efektif selalu mengajar dari limpahan hidupnya yang penuh" (Hendricks, 2009, p. 18). Artinya seluruh pemikiran guru, kesungguhan hati dalam mengajar, tanggung jawab, pengabdian, integritas, dan keteladanan merupakan unsur-unsur penting dari seorang guru/dosen yang efektif.

\section{Metode Pembelajaran}

Seorang guru akan merasa senang dan puas apabila ia dapat menguasai bahan pelajaran. Walaupun begitu, ia juga harus sanggup meneruskan pengetahuan dan semangat belajar kepada murid-muridnya. Untuk melakukan hal itu ia harus bisa mencari cara mengajar yang paling relevan dari pelbagai metode dalam satu masa pengajaran. Pilihan itu bergantung pada kecakapan guru, sifat dan kebutuhan anak didik, materi pelajaran, peralatan, dan fasilitas yang tersedia (Benson, 1974, p. 23).

Andar Ismail berpendapat bahwa ketika guru diperhadapkan pada memilih metode untuk mengajar, maka ia harus memilih metode yang sesuai karena ada banyak sekali metode yang menarik. Setiap metode mempunyai karakteristiknya masing-masing. Sejumlah metode membutuhkan waktu yang lama dalam pelaksanaannya, sementara yang lain membutuhkan waktu yang singkat 
saja. Sedangkan sejumlah metode lainnya memerlukan perlengkapan dan persiapan yang baik dan rinci (Ismail, 2009, p. 93). Gagasan ini menegaskan bahwa persiapan guru tidak boleh asal-asalan (mediocre) dalam merencanakan materi pelajaran, tetapi perlu kesungguhan hati dan sikap bertanggung jawab. Begitu juga sangat diperlukan kejelian dan kemahiran guru dalam menentukan metode apa yang akan digunakannya dalam pembelajaran sehingga menarik perhatian, semangat dan minat belajar dari peserta didiknya.

Di dalam buku Teknik Mengajar, Clarence $\mathrm{H}$. Benson mengusulkan beberapa metode $^{1}$ mengajar dalam konteks gereja, sekolah yakni: bercerita, mengucapkan pelajaran atau partisipasi murid, diskusi, proyek, ceramah, penelaahan Alkitab secara induktif.

\section{Bercerita}

Benson mengungkapkan bahwa bercerita merupakan cara yang paling menarik dan sangat digemari untuk mengajar anak-anak. la membangun pemikiran ini berdasarkan apa yang dilakukan Yesus dalam kitab Injil, Yesus adalah pencerita yang ulung. Dengan memakai tindakan dan kata-kata Yesus melukiskan watak manusia dalam cerita-cerita-Nya. Sebuah cerita yang baik akan menarik, dramatis, penuh aksi, dan sesuai dengan kehidupan. Sebab cerita dapat menimbulkan minat, menarik perhatian dan memikat. Seluruh isi Alkitab merupakan berita yang mendebarkan dan memesonakan, dan sebagian besar dari isi Alkitab itu disajikan dalam bentuk cerita. Ketika mengisahkan cerita-cerita, dapat memakai kata kerja yang banyak, tetapi kata sifat harus sedikit saja. Bahasa yang digunakan harus sederhana agar memudahkan anak didik untuk mengerti dan memahaminya (Benson, 1974, p. 23).
Mengucapkan pelajaran atau

partisipasi murid

Keikutsertaan yang aktif harus lebih diutamakan daripada mendengar. Murid harus ikut terlibat, jika ia hendak memahami dan mengolah kembali pelajaran yang baru diterimanya. Pada intinya pendidikan merupakan proses pengungkapan pikiran, karenanya partisipasi murid melalui pengucapan pelajaran dapat bermanfaat bagi dirinya. Ada tiga bagian dalam pengucapan: pemberian tugas rumah, persiapan para murid, dan partisipasi di kelas (Benson, 1974, p. 25).

\section{Diskusi}

Metode ini akan menghasilkan keterlibatan murid karena meminta mereka menafsirkan pelajaran melalui interaksi antar sesama murid untuk membahas pelajaran yang diberikan oleh guru. Diskusi membantu agar pelajaran dikembangkan terus-menerus atau disusun dan merangsang semangat bertanya dan minat peserta didik (Benson, 1974, p. 26).

\section{Proyek}

Metode proyek memberi kesempatan bagi anak didik atau murid untuk belajar sambil melaksanakannya. Hal-hal seperti kerjasama, toleransi terhadap orang lain, inisiatif, tanggung jawab, kesiagaan dan pertimbangan dikembangkan. Metode ini menguatkan watak serta menyediakan kesempatan untuk memperoleh dan mengembangkan ketrampilan (Benson, 1974, p. 28).

\section{Ceramah}

Metode ceramah membutuhkan persiapan yang baik, sebab keefektifan ceramah itu bergantung kepada penggunaan bahan ajar, gambaran atau lukisan serta keterangan yang mendukungnya. Saat memberi ceramah, guru harus menghindari perkataan yang bertele-tele. la harus mampu berkomunikasi atau menyampaikan materi pelajaran dengan jelas, memakai bahasa 
yang mudah dimengerti oleh audiens, dan membawa peserta didik untuk menyadari dan memecahkan masalah. Dia juga harus menyisihkan ilustrasi atau contoh-contoh yang baik, perlu memakai humor agar peserta didik rileks dan serius dalam mendengar dan mencermatinya (Benson, 1974, p. 28-29).

\section{Penalaahan Alkitab secara induktif}

Metode ini sangat menolong peserta didik dalam melakukan penelaahan atau pemahaman isi Alkitab secara perorangan maupun berkelompok. Metode ini menuntun anak didik untuk menemukan sendiri kebenaran-kebenaran dalam Alkitab. Jika penelahaan Alkitab secara induktif dipakai dalam kelompok, guru harus bertindak sebagai pembimbing dan sumber keterangan. Lebih jauh Benson menjelaskan bahwa ada tiga langkah dalam metode induktif: pengamatan (apa yang dikatakan dalam Alkitab), penafsiran (apa yang dimaksud oleh penulis Kitab), dan penerapan (apa artinya itu bagi saya supaya diterapkan dalam kehidupan sehari-hari) (Benson, 1974, p. 29-30).

\section{Bagaimana Guru atau Dosen Menghadapi Keragaman Gaya Belajar Murid}

Mengetahui dan memahami gaya belajar yang berbeda dari setiap murid akan membantu dan menolong guru maupun dosen dimana pun untuk dapat mendekati berbagai murid dengan menyampaikan informasi dengan gaya yang berbeda-beda (DePorter \& Hernacki, 2012, p. 110). Oleh sebab itu, beberapa ahli pendidikan mengusulkan cara pembelajaran yang dipakai guru atau dosen untuk menghadapi peserta didik yang bergaya belajar tersebut:

\section{Usulan Cynthia Urlich Tobias}

Cara pembelajaran yang dipakai untuk gaya belajar auditori: ajar mereka untuk berlatih dengan ucapan secara sendiri ataupun dengan teman sekelas, minta mereka membaca tugas dengan suara nyaring. Bisa direkam dan kemudian diperdengarkan kembali untuk direnungkan, bimbing mereka untuk mendendangkan apa yang harus dipelajari untuk membuat sajak, lagu, perkecil segala gangguan di ruang belajar; cara pembelajaran untuk pelajar visual: sediakan pensil berwarna, lembaran kertas putih untuk mereka membuat gambar dan tulisan, arahkan mereka untuk membuat coretan atau gambar-gambar, dorong mereka mewarnai kalimat-kalimat dalam buku catatan/buku pelajaran sebisa mungkin sehingga mereka sendiri bisa membuat gambar yang bisa dikaitkan dengan peristiwa, huruf atau kata-kata; cara pembelajaran untuk pelajar kinestetik: motivasi mereka untuk cukup beristirahat sewaktu mempelajari sesuatu, sediakan lembar kertas yang besar untuk membuat gambar dan tulisan, beri mereka buku-buku cerita berisi adegan seru, suruh mereka membuat catatan atau mewarnai apa yang harus dihafal sewaktu mereka mendengarkan (Tobias, 2013, p. 94).

Di dalam buku Every Child Can Succeed, Tobias mengusulkan cara pembelajaran untuk pelajar analitis adalah saat mendisiplin anak yang analitis, bersikaplah spesifik mungkin dalam menangani suatu situasi yang umum membuat mereka kewalahan. Pecahkanlah menjadi bagian-bagian yang lebih kecil dan lebih dapat dikuasai; cara pembelajaran untuk anak yang global adalah mulailah dengan mengungkapkan kasih dan dukungan sebelum berfokus pada persoalannya. Anak-anak tipe ini perlu memelihara perasaan sejahtera secara umum, dan mengetahui kasih Anda tanpa syarat dan tidak tergantung pada kelakuan mereka, bagi anak-anak global pendekatan yang tidak langsung hampir selalu lebih efektif daripada serangan frontal; cara pembelajaran bagi anak sekuensial konkret adalah buatlah mereka berfokus pada apa yang perlu mereka capai, tunjukkan bagaimana mereka dapat mencapai sasaran 
apa pun dengan banyak cara; cara pembelajaran untuk anak sekuensial abstrak adalah untuk anak-anak SA, keadilan merupakan sebuah konsep penting. Apa yang adil bagi satu orang adalah adil bagi semua, guru perlu menunjukkan betapa kita mengasihi anak SA, dan menjelaskan maksud dan tujuan baik ketika mereka dibimbing; cara pembelajaran untuk anak yang random abstrak adalah anak-anak yang bertipe ini sangat suka dengan keharmonisan, karenanya tidak 'perlu' disiplin sebab mereka akan berusaha untuk menyenangkan guru maupun orang lain, dorong mereka untuk melihat bagaimana sikap dan perilaku mereka dapat mempengaruhi temannya; cara pembelajaran bagi anak yang random konkret adalah jangan terlalu menggurui anggaplah mereka pandai dan mampu, berikan penghargaan bagi mereka karena tahu melakukan apa yang benar (Tobias, 2013, pp. 71-79).

\section{Usulan Bobbi DePorter dan Mike Hernacki}

Cara pembelajaran yang dipakai guru atau dosen untuk menghadapi nara didik yang bergaya belajar visual, adalah menggunakan materi visual, seperti slide video, gambar/seni, makalah dalam suatu presentasi; cara pembelajaran untuk gaya belajar auditori: menyampaikan materi dengan berkomunikasi atau bercerita, juga melalui musik, dan diskusi; cara pembelajaran untuk gaya belajar kinestetis ${ }^{2}$ adalah drama, tarian, permainan/games, dan lain-lain; cara pembelajaran untuk gaya sekuensial konkret: catatan atau makalah, pengarahan, pemberian tugas atau proyek; cara pembelajaran untuk gaya acak konkret yaitu: melakukan observasi atau penelitian, berikan tantangan untuk inovasi; cara pembelajaran untuk gaya belajar acak abstrak adalah berikan tugas kelompok atau diskusi, doronglah mereka dengan kata-kata yang membangun ${ }^{3}$, slide gambar; metode pembelajaran untuk pelajar sekuensial abstrak adalah latihlah logika mereka, upayakan keteraturan ${ }^{4}$ suburkan kecerdasan mereka ${ }^{5}$ (Deporter \& Hernacki, 2012, pp. 112-140).

Tentu setiap pelajar dapat mengalami kesulitan-kesulitan atau permasalahan dalam gaya belajarnya. Karena itu, Tobias menjelaskan bagaimana guru dapat menangani kelemahan atau pun kesulitan yang dialami oleh pelajar auditori, pelajar visual, pelajar kinestetis, pelajar analitis, pelajar global, pelajar sekuensial konkret, pelajar sekuensial abstrak, pelajar random abstrak, pelajar random konkret (lih. Tobias, 2013, pp. 82-95).

\section{Yesus Guru Agung Menghadapi Keragaman Murid}

Bahasan berikut ini menguraikan tentang keragaman murid-murid Yesus, orang banyak yang dilayani-Nya, keragaman pendekatan Sang Guru. Tujuan bahasan ini yaitu sebagai landasan teologis bagi guru atau dosen dalam menyikapi keragaman gaya belajar murid.

\section{Keragaman Murid Yesus}

Pada saat Yesus berusia 30 tahun, la mulai terjun dalam pelayanan. Untuk mendampingi-Nya dan akan meneruskan pelayanan-Nya, maka la mulai memanggil beberapa orang untuk menjadi murid-Nya, antara lain: Simon Petrus, Andreas, Yakobus, Yohanes, Filipus, Bartolomeus, Matius, Thomas, Yakobus anak Alfeus, Simon yang disebut orang Selot, Yudas anak Yakobus, dan Yudas Iskariot (Lukas 6:1216). Kebanyakan kedua belas murid Yesus ini berprofesi sebagai nelayan. Mereka berasal dari daerah yang berbeda-beda, misalnya dari Betsaida sebuah kota nelayan kecil di pinggir danau Galilea, dan daerah lainnya.

Sifat atau karakteristik para murid-Nya pun berbeda-beda. Hal ini dapat diklasifikasi dalam beberapa sikap (berdasarkan Yohanes 1:35-51; bdk. Hagelberg, 2009, pp. 68-81; Keddie, 2001; Price, 2011, pp. 20-28) yaitu: antusias, berhati-hati sebelum 
bertindak, skeptis namun jujur, impulsif dan tergesa-gesa, pemarah, keras kepala dan tidak kompromi, ambisius, dan rasionalis.

\section{Sikap yang antusias}

Mereka yang dapat dikatakan sebagai orang-orang yang antusias ini adalah Andreas, Yohanes-penulis injil Yohanes yang dalam catatan tentang peristiwa tersebut tidak menyebutkan namanya sendiri, serta Simon Petrus.

Antusiasme ketiga orang ini nampak dari keputusan mereka untuk segera mengikuti Yesus walaupun bukan Yesus sendiri yang mendorong mereka, namun orang lain yang mengajak mereka. Terhadap Andreas dan Yohanes yang begitu mendengar ajakan dari Yohanes Pembaptis untuk mengikut Yesus langsung mengikutiNya dari belakang, Yesus tidak langsung mengajak mereka untuk menjadi murid-Nya. Di dalam Yohanes 1:38 dicatat la bertanya kepada mereka: "Apakah yang kamu cari?" Pertanyaan ini mengajak mereka berpikir ulang, dengan mengikut Yesus sebenarnya apa yang mereka cari? Di dalam buku Tafsiran Injil Yohanes, Dave Hagelberg menjelaskan pertanyaan Yesus tentang: pertanyaan tersebut, mungkinkah ini bisa mengandung dua arti? Namun ia berpendapat, para pembaca tidak dapat memastikan apakah ini hanya pertanyaan biasa atau mendasar: "Apakah yang kamu harapkan dari kehidupan ini?" (Hagelberg, 2009, p. 70). Di dalam The New Bible Commentary menjelaskan pertanyaan Yesus (Yoh. 1:38) dan pertanyaan dari murid-muridNya dalam menjawab menunjukkan kesungguhan tujuan mereka, yakni untuk mengikuti misi dan ajaran Yesus (2012, p. 270).

\section{Sikap yang berhati-hati sebelum bertindak}

Filipus yang bersikap hati-hati, menimbang terlebih dahulu sebelum bertindak, dan menggerakkan yang bersangkutan untuk melangkah. Sesudah Filipus bertindak mengikut Yesus maka segera ia mengajak Natanael untuk juga menjadi pengikut Yesus (Yoh. 1:43-45).

\section{Sikap yang skeptis namun jujur}

Natanael merasa ragu bahwa Yesus yang berasal dari Nazaret adalah Mesias sebab ia tidak percaya bahwa Mesias berasal dari kota sekecil Nazaret. Terhadap orang yang skeptis namun jujur ini Yesus melakukan pendekatan yang berbeda. la tidak menolak maupun mengajak yang bersangkutan untuk berdebat. Di dalam Yohanes 1:46-49, Yesus menunjukkan pengetahuan-Nya yang melampaui batas alamiah dengan mengungkapkan siapa diri Natanael yang sesungguhnya walaupun Natanael belum pernah berjumpa dengan diri-Nya. Demonstrasi kuasa Yesus dalam bentuk kemahatahuan-Nya ini meyakinkan Natanael bahwa Yesus bukan sekadar seorang guru agama Yahudi, atau seorang rabi, namun benar-benar adalah Anak Allah, Raja Israel.

\section{Impulsif dan tergesa-gesa}

Misalnya rasul Petrus, ia bertindak lebih dahulu, baru kemudian ia memikirkan tindakannya itu. Sebagai contoh ketika ia melompat ke dalam laut pada suatu pagi yang dingin dan berenang menuju Yesus di pantai, padahal ia dapat menunggu sampai perahunya menepi. (Yoh. 21:7; bdk. Price, 2011, p. 20; bdk. Ismail 2008, p. 55). Contoh lain: permintaan Petrus supaya tangan dan mukanya dibasuh sampai ia diberitahukan bahwa ia tidak mempunyai bagian dengan Kristus jika ia menolak (Yoh. 13:9).

\section{Pemarah}

Contohnya Yohanes. Kerapkali perasaannya menjadi panas dan meluapluap. Sifat ini nampak pada waktu Yohanes serta murid-murid lainnya memasuki sebuah Kampung Samaria untuk menyediakan tempat persinggahan bagi Yesus, tetapi ditolak oleh orang-orang Yahudi. Sehingga besar amarah Yohanes, dengan berkata: "Tuhan, apakah Engkau mau supaya kami 
menyuruh api turun dari langit untuk membinasakan mereka? (Luk. 9:54; bdk. Price, 2011, pp. 20-21).

\section{Keras kepala dan tidak kompromi}

Contohnya Yohanes Pembaptis ketika tampil di padang gurun Yudea dengan khotbah yang tidak mengenal kompromi mengenai berita pertobatan sebab Kerajaan Allah sudah dekat! Membuat banyak orang datang bertobat dan memberi diri untuk dibaptis oleh Yohanes di sungai Yordan. Kemudian ia menegur dengan keras dan tegas orang Farisi dan Saduki, dengan berkata: "Hai kamu keturunan ular beludak." (Mat. 3:7-12; bdk. Price, 2011, p. 21).

\section{Ambisius}

Keduabelas murid-Nya bertengkar tentang siapakah yang terbesar di antara mereka. Sedangkan Yakobus dan Yohanes bersaing untuk siapa yang pantas mendapat kedudukan di sebelah kiri dan kanan Yesus kelak (Luk. 22:24; Mrk. 9:33; 10:35-37).

\section{Rasionalis}

Misalnya Tomas, ia meminta bukti yang dapat diterima secara rasional, baru ia percaya bahwa Yesus telah bangkit dari kematian (Yoh. 20:24-29).

Selama tiga setengah tahun la berada bersama-sama dengan murid-murid-Nya untuk membentuk, membina sifat dan kepribadian mereka, serta melatih mereka dalam pelayanan agar menjadi terampil dan profesional. Selain kemahatahuan-Nya, kebersamaan dan persahabatan inilah yang membuat Yesus memahami dengan benar akan sifat dan karakteristik mereka. Karenanya, la memperlakukan dan menangani mereka secara personal berdasarkan keunikan atau kekhasan mereka masing-masing.

\section{Keragaman Orang-orang yang dilayani Yesus}

Apabila mencermati keempat Kitab Injil, maka kita akan menemukan ada beragam orang yang dilayani Yesus, mulai dari anak$a^{a n k}{ }^{6}$, remaja, pemuda hingga orang dewasa. Tuhan Yesus memiliki wibawa dan otoritas yang hebat sehingga pengaruh atau dampak dari pelayanan-Nya terhadap orangorang begitu besar. Itulah yang menyebabkan banyak orang datang berbondong-bondong mencari Dia untuk mengikuti dan mendengarkan ajaran-Nya. Orang-orang tersebut berasal dari berbagai daerah, yakni: Yudea, Yerusalem, Tirus, Sidon, Galilea, Dekapolis, Siria, dan dari seberang sungai Yordan. Yesus tidak hanya mengajar mereka, tetapi juga menolong mereka yang menderita, menyembuhkan yang sakit, serta melepaskan mereka dari berbagai ikatan kuasa dosa dan roh jahat (Luk. 6:17-19; Mat. 4:23-25). Yesus melayani berbagai kelompok orang, ada yang terdiri dari dua belas orang (Mark. 3:13-19; Mat. 10:1-4, 5-15), kelompok tujuh puluh orang (Luk. 10:1-20), 4000 orang (Mark. 8:1-10; Mat. 15:32-39) dan 5000 orang (Luk. 9:10-17; Mrk. 6:30-44). Orientasi atau fokus pelayanan Yesus tidak hanya terhadap bangsa Yahudi saja, tetapi juga bangsa non Yahudi, misalnya perwira Romawi (Luk. 7:110), Kornelius (perwira pasukan Italia) (Kis. 10:1-2), dan perempuan Samaria (Yoh. 4:142). Sebagaimana yang dikemukakan oleh Price bahwa jika kita sebagai guru meninjau orang-orang yang diajar Yesus, kita akan memperoleh suatu gambaran yang memberi pengertian jelas. Orang-orang yang diajar Yesus dapat dibagi dalam tiga kelompok, yaitu: kedua belas murid yang dekat denganNya; pengikut-pengikut lain yang agak banyak jumlahnya, lalu para pengkiritik dan orang-orang yang acuh tak acuh (Price, 2011, pp. 17-18; bdk. Sidjabat, 2009, pp. 267269).

Keragaman orang yang dilayani oleh Tuhan Yesus tersebut di atas menjelaskan bahwa, Yesus datang ke dunia bukan hanya untuk orang Yahudi saja, namun untuk pelbagai bangsa di dunia ini. la mengasihi semua orang, entah dari latar belakang apapun juga. la tidak pernah membedakan 
orang. Semua orang berharga di mata-Nya, karena setiap manusia memiliki harkat dan martabat yang sama. Selaras dengan itu Andar Ismail berpendapat bahwa "Allah menciptakan manusia sebagai makhluk yang berbeda-beda. Namun la tidak membedabedakan orang. Semua orang sama-sama dikasihi-Nya. Setelah melalui perkembangan pemahaman, Rasul Petrus mengakui, 'Sesungguhnya aku telah mengerti bahwa Allah tidak membedakan orang. Allah tidak membedakan orang berdasarkan apa pun...' (Kis. 10:34)" (Ismail, 2008, p. 125).

\section{Keragaman Pendekatan Sang Guru Agung}

Di dalam melakukan pelayanan-Nya terhadap para murid dan orang banyak, Yesus tidak hanya memakai satu pendekatan saja. Ketika la melayani perempuan Samaria di pinggir perigi Yakub, Yesus memulai membangun percakapan terlebih dahulu dengan berkata: "Berilah Aku minum" kepada perempuan Samaria. Jawabannya, "Masakan Engkau seorang Yahudi, minta minum kepadaku, seorang Samaria' (sebab orang Yahudi tidak bergaul dengan orang Samaria)." Pendekatan ini dilakukan Yesus dengan tujuan: Pertama, agar perempuan tersebut merasa dirinya dihargai. Kedua, membangkitkan rasa ingin tahu supaya wanita itu membangun interaksi dialogis atau percakapan dengan Yesus (Yoh. 1:42). Ketiga, karena Yesus ingin menyelamatkan perempuan itu dari dosa-dosanya (Yoh. 4:2526). Percakapan Tuhan Yesus dengan perempuan Samaria itu telah membuahkan hasil transformasi pola pikir dan sikap hati yang bersangkutan. Perubahan yang terjadi dengan sengaja dan sadar adalah hasil belajar. Hasil belajar merupakan bukti bahwa seseorang telah belajar yakni terjadi perubahan tingkah laku dan perubahan yang dialami menyangkut berbagai aspek seperti perubahan dalam pengertian, pemecahan suatu masalah, cara berpikir, ketrampilan, kebiasaan atau sikap (Purba, 2015, p. 27).
Begitu juga tatkala Yesus melayani Nikodemus (Yoh. 3:1-21) pendekatan-Nya berbeda dengan pada saat la menyembuhkan orang buta dan tuli, menyembuhkan orang yang sakit pendarahan, menyembuhkan orang lumpuh, mengusir roh jahat, bahkan membangkitkan orang dari kematian kepada kehidupan. Lois LeBar mengemukakan bahwa Kristus Yesus adalah sang Guru yang ahli, sebab Dia sendiri mengejawantahkan kebenaran itu secara sempurna, Dia memahami secara sempurna murid-murid dan orang-orang yang dilayani-Nya, dan Dia menggunakan metode-metode yang sempurna untuk mengubah umat, Dia mengenal semua orang secara pribadi dan mengetahui sifat manusia, apa yang ada dalam diri manusia (Yoh. 2:2425) (LeBar, 2006, p. 75; bdk. Price, 2011, pp. 105-136; Sidjabat, 2009, pp. 267-269).

Pendekatan yang Yesus lakukan kepada orang dewasa berbeda dengan pendekatan pelayanan-Nya terhadap anakanak. Kitab Injil memaparkan bahwa ketika orang-orang membawa anak-anak kecil datang kepada Yesus, murid-murid-Nya menghalangi mereka. Tetapi Yesus menegur dan memarahi para murid-Nya. Kemudian Yesus menerima, merangkul atau memeluk anak-anak, meletakan tangan-Nya di atas kepala mereka, mendoakan seraya memberkati anak-anak yang datang kepadaNya (Luk. 18:15-17; Mat. 13:13-15; Mrk. 10:13-16).

\section{KESIMPULAN}

Setiap murid memiliki gaya belajar yang berbeda-beda. Perbedaan gaya belajar peserta didik bukanlah suatu pertentangan, melainkan suatu keindahan dari kemajemukan. Oleh sebab itu guru atau dosen harus belajar menghargai gaya belajar dari setiap nara didiknya.

Selain itu, mengenal dan memahami gaya belajar murid sangatlah penting bagi guru atau dosen guna mendisain materi pembelajaran yang relevan. Pemahaman tersebut dapat terjadi melalui proses interaksi 
antara guru dan murid di kelas dan kehidupan di luar kelas (dalam kehidupan sehari-hari). Diperlukan peran guru yang efektif dan kreatif dalam membimbing keragaman gaya belajar murid yang memiliki kecerdasan/intelektual yang berbeda satu dengan lainnya. Kepekaan dalam memakai metode mengajar juga perlu mendapat perhatian serius dari pendidik dalam proses pembelajaran di kelas sehingga menjadi relevan dengan kebutuhan peserta didik.

Guru dan dosen dapat memperkenalkan pengalaman belajar dalam kelas misalnya: mendengar musik, melihat video, percakapan atau diskusi yang interaktif, dsb. Dengan pendekatanpendekatan demikian diharapkan peserta didik akan semakin cerdas dalam belajar serta mengembangkan potensinya dengan

\section{DAFTAR RUJUKAN}

Driyden, Gordon \& Jeannette Vos. (2001). The Learning Revolution. Bandung: Kaifa

Gangle, Kenneth O \& Howard G. Hendricks. (1988). The Christian Educator's Handbook on Teaching. Amerika: Victor Books.

Hendricks, Howard G. (2009). Mengajar Untuk Mengubah Hidup. Yogyakarta: Gloria Grafa.

Hernacki, M \& Bobbi DePorter.(2012). Quantum Learning. Bandung: Kaifa

Ismail, Andar. (2008). Selamat Berkarunia. Jakarta: BPK Gunung Mulia.

Kolb: Learning Styles. (n.d.). Retrieved from www.businessballs.com/kolblearningst yles.htm.

LeBar, Lois E. (2006). Education that is Christian. Malang: Gandum Mas

LeFever, Marlene D. (1988). Creative Teaching Methods. Illinois: Cook Publishing

Mind Styles-Anthony Gregorc. (n.d). Retrieved from http://web.cortland.edu/andersmd/lear ning/gregorc.htm. maksimal baik dalam aspek kognitif, afektif, dan psikomotori, atau yang diistilahkan oleh Aristoteles sebagai ethos, pathos, dan logos.

Pendidik tidak hanya mempunyai fungsi sebagai pengajar, pelatih, pendidik atau pembimbing, peneliti, penemu, motivator, fasilitator, evaluator, dsb. Tetapi lebih dari itu guru atau dosen harus mencontoh apa, bagaimana dan cara Yesus mengajar para muridNya, karena Dia adalah Guru Agung kita. Begitu pula keteladanan guru yang saleh akan sangat berdampak positif bagi peserta didik. Apa yang dilihat, diamati, didengar, dan dirasakan oleh peserta didik atau melalui rasionalitas empiris itu juga yang akan menjadi stimulus bagi murid dalam kegiatan belajar dan implementasi.

Moleong, Lexy J. (2013). Metodologi Penelitian Kualitatif. Bandung: Rosda.

Nasution, S. (2003). Berbagai Pendekatan dalam Proses Belajar Mengajar. Jakarta: Bumi Aksara.

Price, J.M. (2011). Jesus the Teacher. Bandung: LLB.

Purba, Edward. (2015). Pengaruh Strategi Pembelajaran Dengan Webquest dan Efikasi Diri Terhadap Peningkatan Literasi Pengetahuan. Jurnal Teknologi Pendidikan 17(1), 26-36.

Richards, Lawrence O. (2000). Mengajar Alkitab Secara Kreatif. Bandung: Kalam Hidup. (2009). Mengajar Secara Profesional. Bandung: Kalam Hidup.

Sotopo, HB. (2006). Metodologi Penelitian Kualitatif. Surakarta: Universitas Sebelas Maret.

Suyadi. (2014). Teori Pembelajaran Anak Usia Dini. Bandung: Remaja Rosdakarya.

Suyono, Hariyanto. (2012). Belajar dan Pembelajaran. Bandung: Remaja Rosdakarya. 
Sidjabat, BS. (2009). Mengajar Secara Profesional. Bandung: Kalam Hidup

Tobias, Cynthia Ulrich. (2000). Cara Mereka Belajar. Jakarta: Harvest Publication House. . (2013). Setiap Anak Bisa Berhasil. Jakarta: Pionir Jaya.

\section{CATATAN AKHIR}

1. Lihat karya Marlin LeFever di dalam bukunya Creative Teaching Methods. (1988, p. 63297). Bandingkan juga dengan karya Sidjabat, (2009, pp. 232-234 dan Gangel (1988, p. 166-168) yang memaparkan metode kreatif yang dapat dipakai guru atau dosen dalam konteks gereja, sekolah maupun perguruan tinggi.

2. Pelajar kinestetis adalah tipe orang yang tidak bisa duduk diam di kelas. Karenanya perlu mendisain pendekatan belajar kepada mereka dengan metode drama, tarian, permaianan, dan sebagainya.

3. Mengapa mereka perlu dimotivasi? Karena tipe ini sangat perasa. Kepekaannya cukup tinggi.
Tolbert, La Verne. (2000). Teaching Like Jesus. Michigan: Zondervan Publishing House.

Whybray, R.N. (1994). The New Century Bible Commentary. Amerika: Marshal Pickering.

Zuck, Roy B. (1972). Spiritual Power in Your Teaching. Chicago: Moody Press.

4. Sebelum memulai pembelajaran di kelas, ruangan harus rapi dan teratur. Tidak boleh kotor.

5. Caranya melalui memberikan buku bacaan yang berkaitan dengan ilmu filsafat, ilmu riset dan ilmu logika. Sebab tipe ini menyukai rasionalitas.

6. la menghargai dan mengasihi anak-anak kecil. la peduli terhadap mereka, la menerima anak-anak yang datang kepadaNya dan merangkul mereka, serta mendoakan dan memberkati mereka (Mat. 18:2-3, 6, 10; 19:13-15; Mrk. 9:36-37; 10:1316; Luk. 18:15-17). Dengan kata lain Yesus tidak meremehkan anak-anak karena mereka juga berharga di mata-Nya. 